\title{
PERBAIKAN PERTUMBUHAN DAN HASIL KACANG TANAH DI TANAH ULTISOL DENGAN APLIKASI PUPUK P DAN K
}

\author{
IMPROVEMENT OF GROWTH AND YIELD OF PEANUTS \\ IN ULTISOL SOIL WITH APPLICATIONS OF P AND K FERTILIZER
}

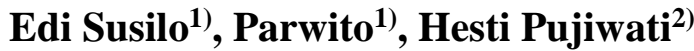 \\ ${ }^{1)}$ Program Studi Agroteknologi, Fakultas Pertanian Universitas Ratu Samban \\ Jl. Jenderal Sudirman No. 87 Arga Makmur Kabupaten Bengkulu Utara \\ ${ }^{2)}$ Program Studi Agroekoteknologi, Fakultas Pertanian Universitas Bengkulu \\ Jl. WR. Supratman Kandang Limun Kota Bengkulu \\ Korespondensi : e-mail : susilo_agr@yahoo.com
}

\begin{abstract}
ABSTRAK
Kacang tanah merupakan salah satu tanaman pangan penting di Indonesia dan mempunyai peran strategis dalam perekonomian nasional, mengingat fungsinya yang multiguna, sebagai sumber pangan, pakan, dan bahan baku industri. Penelitian ini bertujuan untuk mengetahuai dan mendapatkan dosis pupuk $\mathrm{P}$ dan $\mathrm{K}$ yang tepat untuk perbaikan tanaman kacang tanah di tanah Ultisol. Penelitian dilaksanakan di Kebun Percobaan Fakultas Pertanian Universitas Ratu Samban Arga Makmur Kabupaten Bengkulu Utara pada bulan Desember 2018 sampai Maret 2019. Bahan penelitian yang digunakan adalah benih kacang tanah varietas Talam, pupuk organik, pupuk TSP, KCl, Urea dan tanah Ultisol. Penelitian ini dilaksanakan menggunakan Rancangan Acak Kelompok pola faktorial dua faktor. Faktor pertama perlakuan pupuk $\mathrm{P}$ berasal dari TSP terdiri atas empat taraf yaitu $3 \mathrm{~g} \mathrm{tan}^{-1}, 4 \mathrm{~g} \mathrm{tan}^{-1}, 5 \mathrm{~g} \mathrm{tan}^{-1}$, dan kontrol. Faktor kedua perlakuan pupuk $\mathrm{K}$ berasal dari $\mathrm{KCl}$ terdiri atas empat taraf yaitu $3 \mathrm{~g} \mathrm{tan}^{-1}, 4 \mathrm{~g} \mathrm{tan}^{-1}, 5 \mathrm{~g} \mathrm{tan}^{-1}$, dan kontrol. Hasil penelitian menunjukkan bahwa perlakuan TSP $4 \mathrm{~g} \mathrm{tan}^{-1}$ menghasilkan komponen vegetatif dan generatif kacang tanah terbaik. Pada perlakuan kalium tidak terdapat perbedaan yang nyata terhadap semua variabel pengamatan, namun terdapat kecenderungan, perlakuan pupuk $\mathrm{KCl} 4 \mathrm{~g} \mathrm{tan}^{-1}$ menghasilkan komponen generatif yang lebih baik. Tidak terdapat interaksi antara phosfor dan kalium yang nyata terhadap semua variabel pengamatan kacang tanah.
\end{abstract}

Kata kunci : kacang tanah, phosfor, kalium, Ultisol.

\section{ABSTRACT}

Peanut is one of the important food crops in Indonesia and has a strategic role in the national economy, considering its multipurpose function, as a source of food, feed, and industrial raw materials. This study aims to obtain the right dosage of $P$ and $K$ fertilizers on peanut plants in Ultisol soil. The study was carried out at the Experimental Garden of the Faculty of Agriculture, University of Ratu Samban Arga Makmur, Bengkulu Utara in December 2018 until March 2019. The research materials used were peanut seeds of Talam variety, organic fertilizer, phosphate $(P)$ fertilizer, potassium $(K)$ fertilizer, nitogen $(N)$ fertilizer, and Ultisol soil. This study was conducted using a randomized block design with two factor factorial patterns. The first factor was the treatment of $P$ fertilizer from Triple Super Phosphate (TSP) consisting of four levels, namely $3 \mathrm{~g} \mathrm{plant}^{-1}, 4 \mathrm{~g} \mathrm{plant}^{-1}, 5 \mathrm{~g} \mathrm{plant}^{-1}$, and control. The second factor was the treatment of $K$ fertilizer from Muriate Of Potash 
(MOP) consisting of four levels, namely $3 \mathrm{~g} \mathrm{plant}^{-1}, 4 \mathrm{~g} \mathrm{plant}^{-1}, 5 \mathrm{~g}$ plant $^{-1}$, and control. The results showed that the $4 \mathrm{~g}$ plant $^{-1}$ TSP treatment produced the best vegetative and generative components of peanuts. There was no significant difference in potassium treatment, but there was a tendency for the treatment of MOP $4 \mathrm{~g} \mathrm{plant}^{-1}$ fertilizer to produce a better generative component. There is no real interaction between phosphorus and potassium on all variables of peanut observation.

Keywords: peanuts, phosphorus, potassium, Ultisol.

\section{PENDAHULUAN}

Sasaran peningkatan produksi pangan nasional adalah swasembada karbohidrat non terigu yang sekaligus meningkatkan gizi masyarakat melalui penyediaan protein, lemak, vitamin A dan vitamin B. Salah satu tanaman pangan yang dapat memenuhi dan meningkatkan gizi adalah tanaman kacang tanah. Kacang tanah termasuk ke dalam golongan tanaman pangan yang sudah sangat dikenal oleh seluruh masyarakat dunia. Di Indonesia kacang tanah mendapat prioritas kedua untuk dikembangkan dan ditingkatkan produksinya setelah padi. Kebijakan pemerintah ini didorong oleh meningkatnya kebutuhan untuk pangan, bahan baku industri (makanan dan minyak goreng), dan pakan hewan (ternak dan ikan) (Cahyono, 2007).

Kacang tanah merupakan salah satu tanaman pangan penting di Indonesia dan mempunyai peran strategis dalam perekonomian nasional, mengingat fungsinya yang multiguna. Dalam 100 gram kacang tanah mengandung karbohidrat 21,1 g, protein $25 \mathrm{~g}$, lemak 43 $\mathrm{g}$, vitamin B1 0,30 mg, vitamin C $3 \mathrm{mg}$, kalsium $58 \mathrm{mg}$ dan fosfor $335 \mathrm{mg}$. Kacang tanah kaya akan asam lemak tidak jenuh yang dapat menurunkan kolesterol darah. Selain itu, kacang tanah juga dapat mencegah penyakit jantung dan kencing manis (Astawan, 2009). Kebutuhan kacang tanah secara nasional dari tahun ke tahun semakin meningkat dengan rata-rata 900.000 ton/tahun, sedangkan produksi rata-rata hanya 771.022 ton/tahun $(85,67 \%)$ dengan volume impor rata-rata 163.745 ton/tahun. Rata-rata per tahun untuk luas panen berkurang 2,28\% sedangkan produksi berkurang 1,02\% dengan demikian menunjukkan produksi kacang tanah perlu ditingkatkan (Direktorat Jenderal Tanaman Pangan 2012). Kebutuhan yang cukup besar ini, jika tidak diimbangi dengan peningkatan produksi yang memadai, akan menyebabkan Indonesia harus mengimpor kacang tanah dalam jumlah besar dimasa mendatang.

Tanah Ultisol merupakan bagian terluas dari lahan kering yang tersebar luas di pulau Sumatera, Kalimantan, Sulawesi, 
Papua serta sebagian kecil di pulau Jawa, terutama di wilayah Jawa Barat. Luas tanah Ultisol di Indonesia dari tahunketahun semakin meluas, sejalan dengan makin meningkatnya intensitas penebangan hutan, baik dalam skala besar maupun dalam skala kecil yang dilakukan oleh masyarakat setempat untuk memenuhi kebutuhan kayu bakar, bahan bangunan dan keperluan berladang (Munir, 1996). Kelemahan tanah Ultisol sebagai media tumbuh tanaman adalah karena tanah tersebut umumnya bereaksi masam.

Tanah Ultisol mempunyai $\mathrm{pH}$ tanah dan kejenuhan basa (berdasarkan jumlah kation) yang rendah $<35$. Kejenuhan $\mathrm{Al}$ dan Fe cukup tinggi merupakan racun bagi tanaman dan mengakibatkan adanya fiksasi P sehingga unsur P kurang tersedia. Kapasitas Tukar Kation (KTK) yang relatif rendah memperlihatkan kandungan bahan organik yang rendah pada semua horizon kecuali di horizon A (bagian atas) yang sangat tipis. Tanah Ultisol mempunyai daya simpan air dan kemantapan agregat tanah menyebabkan tanah ini rentan terhadap erosi dan menjadi kendala pada areal berlereng. Walaupun tanah ultisol diidentikkan dengan tanah yang tidak subur, dimana mengandung bahan organik yang rendah, nutrisi rendah dan $\mathrm{pH}$ rendah (kurang dari 5,5) tetapi bisa dimanfaatkan untuk lahan pertanian potensial jika dilakukan pengelolaan yang memperhatikan kendala yang ada (Silaen dkk, 2013).

Salah satu upaya untuk meningkatkan produktivitas tanaman kacang tanah di lahan Ultisol adalah melalui pemupukan. Pemupukan memegang peranan penting untuk menyediakan dan menggantikan unsur hara yang habis terpakai dalam proses pertumbuhan, perkembangan, dan produksi suatu tanaman serta memperbaiki struktur tanah yang mengalami kerusakan (Mulyani, 2010). Salah satu jenis pupuk yang digunakan untuk memperbaiki kesuburan tanah adalah pupuk anorganik. Unsur hara $\mathrm{N}, \mathrm{P}$ dan $\mathrm{K}$ merupakan unsur hara utama untuk pertumbuhan kacang tanah. Unsur $\mathrm{N}$ merupakan unsur hara yang berperan untuk pembentukan organ vegetatif tanaman dan merupakan unsur utama pembentuk asam amino dan protein.

Unsur P bagi tanaman merupakan unsur hara esensial makro yang penting setelah nitrogen. Tanaman mengambil hara $\mathrm{P}$ dalam jumlah besar, walaupun jumlah $\mathrm{P}$ yang dibutuhkan tanaman atau yang terdapat dalam tanaman lebih kecil dibandingkan dengan $\mathrm{N}$ dan $\mathrm{K}$. Namun, $\mathrm{P}$ dapat dianggap berperan sangat penting dalam kehidupan tanaman. Unsur P yang diserap tanaman dalam bentuk ion anorganik cepat berubah menjadi senyawa phosfor organik. $\mathrm{P}$ bersifat mudah bergerak diantara jaringan tanaman. Kadar 
$\mathrm{P}$ dalam tanaman pada saat vegetatif berkisar antara $0,3 \%-0,5 \%$ dari berat kering tanaman (Salisbury dan Ross, 1992). $P$ berperan penting dalam transfer energi pada sel tanaman, pembentukan membran sel dan meningkatkan efisiensi dalam penggunaannya (Agustina, 2004). Selain itu, P sangat diperlukan oleh tanaman pada saat pembentukan biji dan buah. Posfor juga berguna untuk mempercepat pemasakan buah pada tanaman. Kekurangan P pada kebanyakan tanaman terjadi sewaktu tanaman masih muda, hal ini karena belum adanya kemampuan yang seimbang antara penyerapan $\mathrm{P}$ yang tersedia oleh akar dan $\mathrm{P}$ yang tersedia dalam tanah.

Unsur $\mathrm{K}$ sangat penting dalam proses pembentukan biji kacang tanah bersama hara $\mathrm{P}$ disamping juga penting sebagai pengatur berbagai mekanisme dalam proses metabolik seperti fotosintesis, transportasi hara dari akar ke daun, translokasi asimilat dari daun ke seluruh jaringan tanaman (Sumarno et al., 1986). Penelitian ini bertujuan untuk mengetahui dan mendapatkan dosis pupuk $\mathrm{P}$ dan $\mathrm{K}$ yang tepat untuk perbaikan budidaya tanaman kacang tanah di tanah Ultisol.

\section{BAHAN DAN METODE}

Penelitian dilaksanakan di Kebun Percobaan Fakultas Pertanian Universitas
Ratu Samban Arga Makmur Kabupaten Bengkulu Utara pada bulan Desember 2018 sampai Maret 2019. Bahan penelitian yang digunakan adalah benih kacang tanah varietas Talam, pupuk organik, pupuk TSP, KCl, Urea dan tanah Ultisol. Alat yang digunakan adalah cangkul, penggaris, polybag, sabit, label, timbangan digital, dan alat tulis. Penelitian ini dilaksanakan menggunakan Rancangan Acak Kelompok pola faktorial dua faktor. Faktor pertama perlakuan pupuk $\mathrm{P}$ berasal dari TSP terdiri atas empat taraf yaitu $3 \mathrm{~g} \mathrm{tan}^{-1}(1,4 \mathrm{~g}$ $\left.\mathrm{P}_{2} \mathrm{O}_{5}\right), 4 \mathrm{~g} \mathrm{tan}^{-1}\left(1,8 \mathrm{~g} \mathrm{P}_{2} \mathrm{O}_{5}\right), 5 \mathrm{~g} \mathrm{tan}^{-1}(2,3$ g $\mathrm{P}_{2} \mathrm{O}_{5}$ ), dan kontrol/tanpa pemupukan. Faktor kedua perlakuan pupuk $\mathrm{K}$ berasal dari $\mathrm{KCl}$ terdiri atas empat taraf yaitu $3 \mathrm{~g}$ $\tan ^{-1}\left(1,8 \mathrm{~g} \mathrm{~K}_{2} \mathrm{O}\right), 4 \mathrm{~g} \mathrm{tan}^{-1}\left(2,4 \mathrm{~g} \mathrm{~K}_{2} \mathrm{O}\right), 5 \mathrm{~g}$ $\tan ^{-1} \quad\left(3 \quad \mathrm{~g} \quad \mathrm{~K}_{2} \mathrm{O}\right)$, dan kontrol/tanpa pemupukan.

Penelitian ini diawali dengan pengambilan bahan media tanam berupa tanah Ultisol. Tanah Ultisol yang telah dikumpulkan sebanyak $640 \mathrm{~kg}$ dicampur dengan pupuk organik secara komposit untuk mendapatkan media yang homogen. Setelah pencampuran media secara homogen selesai, selanjutnya tanah tersebut dibagi ke dalam 64 polybag dengan bobot per polybag $10 \mathrm{~kg}$. Media tanam di polybag ini didiamkan selama 1 minggu dengan tujuan untuk mendapatkan media yang baik untuk penelitian nantinya. Semua media di dalam polybag ini disusun 
secara teratur sesuai denah percobaan yang dibuat yaitu rancangan acak kelompok. Masing-masing kombinasi perlakuan dalam satu ulangan diacak secara lengkap.

Benih kacang tanah disiapkan dua minggu sebelum dilakukan penanaman. Benih kacang tanah varietas Talam ini diperoleh dari Balitkabi Malang, dengan daya kecambah tinggi di atas $90 \%$. Benih yang akan ditanam pada penelitian ini berasal dari polong. Polong kacang tanah dikupas sehari sebelum penanaman. Benih yang telah dikupas dijemur di bawah terik matahari selama 3 jam bertujuan mendapatkan benih yang kering dan mengurangi kelembaban.

Benih kacang tanah sebelumnya dilakukan sortasi untuk mendapatkan benih yang seragam dan sehat bebas dari hama dan penyakit. Sebelum dilakukan penanaman, benih kacang tanah diinfeksi dengan legin rhizobium untuk merangsang bintil akar nantinya. Penanaman dilakukan dengan cara membuat lubang tanam terlebih dahulu sebanyak 3 lubang setiap polybag. Insektisida berupa Karbofuran diaplikasikan sebelum tanam. Penanaman dilakukan memasukkan benih kacang tanah per lubang satu benih. Lubang yang telah tertanam benih ditutup dengan tanah topsoil.

Pemeliharaan meliputi penyiraman tanaman sehari sekali bila tidak hujan, pengendalian hama dan penyakit menggunakan pestisida yang disesuaikan dengan jenis serangan hama atau penyakit. Penyiangan gulma dilakukan secara manual dengan mencabut gulma secara langsung yang tumbuh di media polybag. Panen kacang tanah dilakukan apabila telah berumur 95 hari setelah tanam yang mempunyai ciri daun gugur, warna batang kecoklatan dan kering.

Variabel pengamatan meliputi tinggi tanaman, jumlah daun, jumlah cabang, jumlah polong dan bobot polong segar. Data pengamatan dianalisis dengan sidik ragam untuk mengetahui pengaruh perlakuan yang dicobakan dan apabila dari hasil analisis tersebut berpengaruh nyata maka diuji lanjut BNT pada taraf kepercayaan 95\% (Mattjik dan Sumertajaya, 2006).

\section{HASIL DAN PEMBAHASAN}

Pengamatan terhadap variabel pertumbuhan dan hasil kacang tanah meliputi tinggi tanaman, jumlah daun, jumlah cabang, jumlah polong dan bobot polong segar. Berdasarkan hasil uji $\mathrm{F}$ menunjukkan bahwa perlakuan phosfor berpengaruh nyata terhadap variabel tinggi tanaman umur 6 MST, jumlah daun umur 6 MST, jumlah cabang, jumlah polong, dan bobot polong segar, namun tidak berpengaruh nyata terhadap variabel tinggi tanaman umur 4 MST, dan jumlah daun umur 4 MST. Pada perlakuan kalium 
menunjukkan tidak terdapat perbedaan yang nyata terhadap semua variabel pengamatan. Tidak terdapat interaksi antara phosfor dan kalium yang nyata terhadap semua variabel pengamatan (Tabel 1). Unsur hara di dalam tanah mempunyai peranan masing-masing untuk mendukung pertumbuhan dan perkembangan tanaman. Menurut Bagaskara (2011), unsur makro N, P, dan $\mathrm{K}$ mempunyai peranan masing-masing untuk tanaman diantaranya unsur nitrogen dibutuhkan untuk pertumbuhan daun dan pembentukan batang serta cabang. Khusus pada kacang-kacangan yang memiliki nodul akar, dapat memanfaatkan bakteri yang ada di udara. Unsur phosfor diperlukan bagi tanaman untuk perkembangan biji dan akar. Sementara unsur kalium berfungsi untuk membentuk bunga dan buah serta membantu tanaman melawan penyakit.
Pada variabel tinggi tanaman umur 4 MST menunjukkan bahwa tidak terdapat perbedaan yang nyata, namun terdapat perbedaan yang nyata pada umur 6 MST. Tinggi tanaman pada umur 6 MST menunjukkan bahwa perlakuan phosfor berupa TSP $3 \mathrm{~g} \mathrm{tan}^{-1}$ dan TSP $4 \mathrm{~g} \mathrm{tan}^{-1}$ menghasilkan tinggi tanaman tertinggi dan berbeda nyata dengan kontrol dan tidak berbeda nyata dengan TSP $5 \mathrm{~g} \mathrm{tan}^{-1}$. Pada perlakuan kalium menunjukkan tidak berpengaruh nyata pada umur 4 MST dan 6 MST (Tabel 2). Hal ini menunjukkan bahwa perlakuan phosfor TSP $3 \mathrm{~g} \mathrm{tan}^{-1}$ dan TSP $4 \mathrm{~g} \mathrm{tan}^{-1}$ telah mampu menambah tinggi tanaman. Menurut Ikhsani, et al., (2018) perlakuan 2 1/ha Azotobacter chroococcum $+150 \mathrm{~kg} / \mathrm{ha}$ pupuk NPK meningkatkan tinggi tanaman dan bobot kering akar, sedangkan perlakuan 300 $\mathrm{kg} / \mathrm{ha}$ pupuk NPK meningkatkan bobot kering tajuk tanaman.

Tabel 1. Rekapitulasi Hasil Uji F aplikasi P dan K terhadap Pertumbuhan dan Hasil Kacang Tanah di Tanah Ultisol

\begin{tabular}{clccc}
\hline No & Variabel pengamatan & $\begin{array}{c}\text { Phosfor } \\
(\mathrm{P})\end{array}$ & $\begin{array}{c}\text { Kalium } \\
(\mathrm{K})\end{array}$ & $\begin{array}{c}\text { Interaksi } \\
(\mathrm{P} \times \mathrm{K})\end{array}$ \\
\hline 1 & Tinggi tanaman 4 MST & $0,23 \mathrm{tn}$ & $2,16 \mathrm{tn}$ & $1,32 \mathrm{tn}$ \\
2 & Tinggi tanaman 6 MST & $12,26 * *$ & $0,94 \mathrm{tn}$ & $0,65 \mathrm{tn}$ \\
3 & Jumlah daun 4 MST & $0,18 \mathrm{tn}$ & $0,98 \mathrm{tn}$ & $1,77 \mathrm{tn}$ \\
4 & Jumlah daun 6 MST & $6,38 * *$ & $1,69 \mathrm{tn}$ & $1,32 \mathrm{tn}$ \\
5 & Jumlah cabang & $3,95 *$ & $1,20 \mathrm{tn}$ & $0,86 \mathrm{tn}$ \\
6 & Jumlah polong & $6,19 * *$ & $0,47 \mathrm{tn}$ & $1,13 \mathrm{tn}$ \\
7 & Bobot polong & $5,03 * *$ & $0,32 \mathrm{tn}$ & $0,98 \mathrm{tn}$ \\
\hline
\end{tabular}

Keterangan : $*=$ berbeda nyata

$* *$ = berbeda sangat nyata

tn = tidak berbeda nyata 
Tabel 2. Rataan Tinggi Tanaman Kacang Tanah dengan Aplikasi Pupuk P dan K di Tanah Ultisol

\begin{tabular}{ccc}
\hline \multirow{2}{*}{ Perlakuan } & \multicolumn{2}{c}{ Tinggi tanaman $(\mathrm{cm})$} \\
\cline { 2 - 3 } & 4 MST & $6 \mathrm{MST}$ \\
\hline Phosfor (P) : & & \\
TSP 3 g tan & 19,55 & $45,17 \mathrm{a}$ \\
TSP 4 g tan & 19,29 & $45,17 \mathrm{a}$ \\
TSP 5 g tan & 19,58 & $44,21 \mathrm{a}$ \\
Kontrol & 19,79 & $35,00 \mathrm{~b}$ \\
\hline Kalium (K) : & & \\
KCl 3 g tan & 19,48 & 40,58 \\
KCl 4 g tan & 19,37 & 43,29 \\
KCl 5 g tan & 19,58 & 43,58 \\
Kontrol & 19,79 & 42,08 \\
\hline
\end{tabular}

Keterangan : angka-angka yang diikuti huruf yang sama pada kolom yang sama tidak berbeda nyata pada uji BNT taraf $5 \%$.

Pada variabel jumlah daun umur 4 MST menunjukkan bahwa tidak terdapat perbedaan yang nyata, namun terdapat perbedaan yang nyata pada umur 6 MST. Pada variabel jumlah daun umur 6 MST menunjukkan bahwa perlakuan phosfor TSP $5 \mathrm{~g} \mathrm{tan}^{-1}$ menghasilkan jumlah daun terbanyak namun tidak berbeda nyata dengan TSP $4 \mathrm{~g} \mathrm{tan}^{-1}$, TSP $3 \mathrm{~g} \mathrm{tan}^{-1}$ dan berbeda nyata dengan kontrol. Hal ini menunjukkan bahwa perlakuan dosis phosfor yang paling tinggi menghasilkan jumlah daun terbanyak. Perlakuan phosfor menghasilkan jumlah daun yang lebih banyak. Perlakuan phosfor mampu meningkatkan jumlah daun. Pada perlakuan kalium menunjukkan tidak berpengaruh nyata pada umur 4 MST dan 6 MST. Terdapat kecenderungan bahwa $\mathrm{KCl} 5 \mathrm{~g} \mathrm{tan}^{-1}$ menghasilkan jumlah daun terbanyak (Tabel 3). Menurut Buckam dan Brady (1982) pada tanaman, nitrogen berfungsi untuk memperbesar ukuran daun dan meningkatkan prosentase protein. Ukuran daun yang besar dan protein yang banyak akan meningkatkan berat kering tanaman. Hal ini juga dimungkinkan pemupukan dengan $\mathrm{P}$ dengan dosis $100 \mathrm{~kg} \mathrm{ha}^{-1}$ dan $\mathrm{K}$ sebesar $75 \mathrm{~kg} \mathrm{ha}^{-1}$ dapat mendorong fotosintesis tanaman sehingga berat kering tanaman meningkat. 
Tabel 3. Rataan Jumlah Daun Kacang Tanah dengan Aplikasi Pupuk P dan K di Tanah Ultisol

\begin{tabular}{ccc}
\hline \multirow{2}{*}{ Perlakuan } & \multicolumn{2}{c}{ Jumlah daun (helai) } \\
\cline { 2 - 3 } & 4 MST & 6 MST \\
\hline Phosfor (P) : & 10,33 & $32,67 \mathrm{a}$ \\
TSP 3 g tan & 10,08 & $36,33 \mathrm{a}$ \\
TSP 4 g tan & 10,25 & $36,42 \mathrm{a}$ \\
TSP 5 g tan & 10,13 & $26,25 \mathrm{~b}$ \\
Kontrol & & \\
Kalium (K) : & 10,17 & 30,58 \\
KCl 3 g tan & 9,83 & 35,00 \\
KCl 4 g tan & 10,42 & 35,08 \\
KCl 5 g tan & 10,38 & 31,00 \\
Kontrol & & \\
\hline
\end{tabular}

Keterangan : angka-angka yang diikuti huruf yang sama pada kolom yang sama tidak berbeda nyata pada uji BNT taraf $5 \%$.

Pada variabel jumlah cabang menunjukkan bahwa perlakuan phosfor terdapat perbedaan yang nyata. Perlakuan TSP $4 \mathrm{~g} \tan ^{-1}$ menghasilkan jumlah cabang terbanyak meskipun tidak berbeda nyata dengan perlakuan TSP $3 \mathrm{~g} \mathrm{tan}^{-1}$, TSP $5 \mathrm{~g} \mathrm{tan}{ }^{-1}$, namun berbeda nyata dengan kontrol. Hal ini menunjukkan bahwa perlakuan TSP $4 \mathrm{~g} \tan ^{-1}$ sudah mampu menghasilkan jumlah cabang terbanyak. Menurut Sumarno (1986) hara $\mathrm{P}$ penting sebagai pengatur berbagai mekanisme dalam proses metabolik seperti fotosintesis, transportasi hara dari akar ke daun, translokasi asimilat dari daun ke seluruh jaringan tanaman. Pada perlakuan kalium menunjukkan tidak berpengaruh nyata, terdapat kecenderungan bahwa $\mathrm{KCl} 5 \mathrm{~g} \tan ^{-1}$ menghasilkan jumlah cabang terbanyak (Tabel 4). Tersedianya hara P dan K akan menyebabkan proses fotosintesis berjalan lancar. Menurut Purbayanti et al., (1995) $\mathrm{N}$ bersama dengan $\mathrm{P}$ akan membentuk protein, karbohidrat, asam nukleat dan ditranslokasikan oleh unsur $\mathrm{K}$ sehingga berat kering meningkat. Phosfat sangat diperlukan oleh tanaman pada saat pembentukan biji sehingga menjadi bentuk yang sempurna dan untuk mempercepat kemasakan buah serta tahan terhadap kekeringan.

Pada variabel jumlah polong menunjukkan bahwa perlakuan phosfor terdapat perbedaan yang nyata. Perlakuan TSP $4 \mathrm{~g} \quad \tan ^{-1}$ menghasilkan jumlah polong terbanyak meskipun tidak berbeda nyata dengan perlakuan TSP $3 \mathrm{~g} \mathrm{tan}^{-1}$, TSP $5 \mathrm{~g} \tan ^{-1}$, namun berbeda nyata dengan kontrol. Menurut Agustina (2004). phosfat berperan penting dalam transfer energi pada sel tanaman, pembentukan 
membran sel dan meningkatkan efisiensi dalam penggunaannya. Hasil penelitian Siswadi (2006) mengemukakan bahwa pemberian pupuk TSP bagi tanaman kacang tanah yang terbaik adalah 150 $\mathrm{kg} / \mathrm{ha}$, seluruh pupuk diberikan saat tanam dan memberikan hasil 1,5 ton/ha. Pada perlakuan kalium menunjukkan tidak berpengaruh nyata, terdapat kecenderungan bahwa $\mathrm{KCl} 4 \mathrm{~g} \tan ^{-1}$ dan $\mathrm{KCl} 5 \mathrm{~g} \mathrm{tan}^{-1}$ menghasilkan jumlah polong terbanyak (Tabel 4).

Pada variabel bobot polong segar menunjukkan bahwa perlakuan phosfor terdapat perbedaan yang nyata. Perlakuan TSP $4 \mathrm{~g} \mathrm{tan}^{-1}$ menghasilkan bobot polong segar tertinggi meskipun tidak berbeda nyata dengan perlakuan TSP $3 \mathrm{~g} \mathrm{tan}^{-1}$, dan TSP $5 \mathrm{~g} \mathrm{tan}{ }^{-1}$, namun berbeda nyata dengan kontrol. Phosfor sangat diperlukan oleh tanaman pada saat pembentukan biji dan buah. Phosfor juga berguna untuk mempercepat pemasakan buah pada tanaman. Kekurangan P pada kebanyakan tanaman terjadi sewaktu tanaman masih muda, hal ini karena belum adanya kemampuan yang seimbang antara penyerapan $\mathrm{P}$ yang tersedia oleh akar dan $\mathrm{P}$ yang tersedia dalam tanah. Efisiensi dan efektifitas pemupukan serta dosis dan cara pemupukan yang tepat dan baik adalah salah satu faktor yang membantu dalam peningkatkan produksi tanaman. Pupuk TSP sangat dianjurkan untuk digunakan dalam budidaya tanaman kacangkacangan. Kegunaan unsur phosfat $(\mathrm{P})$ yaitu berperan penting dalam transfer energi pada sel tanaman, pembentukan membran sel dan meningkatkan efisiensi dalam penggunaannya (Agustina, 2004). Selain itu, Phosfor sangat diperlukan oleh tanaman pada saat pembentukan biji dan buah. Phosfor juga berguna untuk mempercepat pemasakan buah pada tanaman. Pada perlakuan kalium menunjukkan tidak berpengaruh nyata, terdapat kecenderungan bahwa $\mathrm{KCl} 4 \mathrm{~g}$ $\tan ^{-1}$ menghasilkan bobot polong segar tertinggi (Tabel 4). Menurut Arista, et al., (2015) kombinasi dosis pupuk P dan K memberikan pengaruh nyata terhadap bobot biji kering kacang tanah, dosis pupuk $300 \mathrm{~kg} / \mathrm{ha} \mathrm{SP-36} \mathrm{dan} 225 \mathrm{~kg} / \mathrm{ha} \mathrm{ZK}$ yang dapat meningkatkan $57 \%$ bobot biji kering jika dibandingkan dengan dosis pupuk rekomendasi. Pupuk K yang diberikan juga berperan dalam menghasilkan bobot biji yang tinggi. Buckman dan Brady (1982) menambahkan bahwa secara garis besar unsur $\mathrm{K}$ memberikan efek keseimbangan baik pada $\mathrm{N}$ maupun $\mathrm{P}$, karena itu $\mathrm{K}$ penting dalam komposisi pupuk campuran. Menurut Novizan (2002), secara umum peranan $\mathrm{K}$ berhubungan dengan proses metabolisme seperti fotosintesis dan respirasi. 
Tabel 4. Rataan Jumlah Cabang, Jumlah Polong dan Bobot Polong Segar Kacang Tanah dengan Aplikasi Pupuk P dan K di Tanah Ultisol

\begin{tabular}{cccc}
\hline Perlakuan & $\begin{array}{c}\text { Jumlah cabang } \\
\text { (batang) }\end{array}$ & $\begin{array}{c}\text { Jumlah polong } \\
\text { (buah) }\end{array}$ & $\begin{array}{c}\text { Bobot polong } \\
\text { segar (g) }\end{array}$ \\
\hline Phosfor (P) : & & & \\
TSP 3 g tan & & $22,50 \mathrm{a}$ & $41,10 \mathrm{ab}$ \\
TSP 4 g tan & $3,42 \mathrm{ab}$ & $27,92 \mathrm{a}$ & $51,07 \mathrm{a}$ \\
TSP 5 g tan & $4,08 \mathrm{a}$ & $25,33 \mathrm{a}$ & $46,68 \mathrm{a}$ \\
Kontrol & $3,83 \mathrm{a}$ & $15,25 \mathrm{~b}$ & $28,84 \mathrm{~b}$ \\
\hline Kalium (K) : & $2,75 \mathrm{~b}$ & & \\
KCl 3 g tan & & 21,25 & 39,95 \\
KCl 4 g tan & 3,33 & 24,08 & 45,32 \\
KCl 5 g tan & 3,42 & 24,00 & 41,93 \\
Kontrol & 4,00 & 21,67 & 40,48 \\
\hline
\end{tabular}

Keterangan : angka-angka yang diikuti huruf yang sama pada kolom yang sama tidak berbeda nyata pada uji BNT taraf 5\%.

\section{KESIMPULAN}

Perlakuan phosfor berpengaruh nyata terhadap tinggi tanaman dan jumlah daun umur 6 MST, jumlah cabang, jumlah polong, dan bobot polong segar. Perlakuan TSP $4 \mathrm{~g} \mathrm{tan}{ }^{-1}$ menghasilkan komponen vegetatif dan generatif kacang tanah terbaik. Pada perlakuan kalium tidak terdapat perbedaan yang nyata terhadap semua variabel pengamatan. Namun terdapat kecenderungan, perlakuan pupuk $\mathrm{KCl} \quad 4 \quad \mathrm{~g} \quad \tan ^{-1}$ menghasilkan komponen generatif yang lebih baik. Tidak terdapat interaksi antara phosfor dan kalium yang nyata terhadap semua variabel pengamatan kacang tanah.

\section{DAFTAR PUSTAKA}

Agustina, L. 2004. Dasar Nutrisi Tanaman. Rineka Cipta. Jakarta.

Arista, D. Suryono. Sudadi. 2015. Efek dari kombinasi pupuk N, P dan K terhadap pertumbuhan dan hasil kacang tanah pada lahan kering
Alfisol. Agrosains 17(2): 49-52, 2015; ISSN: 1411-5786.

Astawan, M. 2009. Sehat dengan Hidangan Kacang dan Biji-bijian. Penebar Swadaya. Jakarta.

Bagaskara, 2011. Pengaruh pemberian pupuk NPK terhadap pertumbuhan Kacang jenis pelanduk dan gajah. http://baskara90. wordpress.com/2018/05/20/pengar uh- pemberian-pupuk-npkterhadap- pertumbuhan-kacangjenis-pelanduk-dan- gajah/. Diakses pada tanggal 20 Mei 2018.

Buckman, H.O., Brady, B. C. 1982. Ilmu Tanah (Terjemahan: Soegiman \& Buana I D M). Jakarta (ID): Bhratara Karya Aksara.

Cahyono, B. 2007. Budidaya Kacang Tanah. Aneka Ilmu: Semarang.

Direktorat Jenderal Tanaman Pangan. 2012.

Kacang

Tanah.http://pusdatin.setjen.deptan .go.id/ditjentp/fil es/Bulletin_Kcang_Tanah.pdf.

Diakses pada tanggal 21 Maret 2018.

Ikhsani, D. R, Hindersah. D, Herdiyantoro. 2018. Pertumbuhan tanaman kacang tanah (Arachis hypogea L. Merril) setelah aplikasi 
Azotobacter chroococcum dan pupuk NPK. AGROLOGIA: Volume 7, Nomor 1, April 2018, halaman 1-8 p-ISSN 2301-7287; e-ISSN 2580-9636.

Mattjik, A, A. Sumertajaya, I, M. 2006. Perancang Percobaan dengan Aplikasi SAS dan MINITAB. Bogor: IPB Press.

Mulyani, S. M. 2010. Pupuk dan Cara Pemupukan. Rineka Cipta. Jakarta.

Munir, M.1996. Tanah - Tanah Utama Indonesia. PT Dunia Pustaka Jaya. Jakarta.

Novizan. 2002. Petunjuk Pemupukan dan Efektif. Jakarta (ID) : Agromedia Pustaka.

Purbayanti, Lukiwati dan Trimulatsih. 1995. Dasar- dasar Ilmu Tanah. terjemahan dari Fundamentals of Soil Science. Yogyakarta (ID): Gadjah Mada University Press.

Salibury, F.B. and Ross, C.W. 1992. Plant Physiology Wardswort Publ. Co Belmont: California.

Silaen, S, O. Sitepu, E, F., Siagian, B. 2013. Respons pertumbuhan bibit kakao terhadap vermikompos dan pupuk P. Jurnal Online Agroteknologi. Vol 1 (4).

Siswadi. 2006. Budidaya Tanaman Palawija. Citra Aji Parama. Yogyakarta.

Sumarno. 1986. Teknik Budidaya Kacang Tanah. Sinar Baru: Bandung. 